\title{
Detection of virulence-associated genes of Pasteurella multocida isolated from cases of fowl cholera by multiplex-PCR ${ }^{1}$
}

\author{
Thales Q. Furian ${ }^{2 *}$, Karen A. Borges ${ }^{2}$, Silvio L.S. Rocha², Everton E. Rodrigues², \\ Vladimir P. do Nascimento ${ }^{2}$, Carlos T.P. Salle ${ }^{2}$ e Hamilton L.S. Moraes ${ }^{2}$
}

\begin{abstract}
Furian T.Q., Borges K.A., Rocha S.L.S., Rodrigues E.E., Nascimento V.P., Salle C.T.P. \& Moraes H.L.S. 2013. Detection of virulence-associated genes of Pasteurella multocida isolated from cases of fowl cholera by multiplex-PCR. Pesquisa Veterinária Brasileira 33(2):177-182. Centro de Diagnóstico e Pesquisa em Patologia Aviária, Faculdade de Medicina Veterinária, Universidade Federal do Rio Grande do Sul, Av. Bento Gonçalves 8824, Porto Alegre, RS 91540-000, Brazil. E-mail: thales.furian@ufrgs.br

The current systems of breeding poultry, based on high population density, increase the risk of spreading pathogens, especially those causing respiratory diseases and those that have more than one host. Fowl Cholera (FC) is one such pathogen, and even though it represents one of several avian diseases that should be considered in the differential diagnosis of notifiable diseases that present with sudden death, the pathogenesis and virulence factors involved in FC are still poorly understood. The objective of this study was to investigate twelve genes related to virulence in 25 samples of Pasteurella multocida isolated from FC cases in the southern region of Brazil through the development of multiplex PCR protocols. The protocols developed were capable of detecting all of the proposed genes. The $o m p H$, oma87, sodC, $h g b A, h g b B$, exBD-ton $B$ and $\operatorname{nan} B$ genes were present in $100 \%$ of the samples (25/25), the sodA and nanH genes were present in 96\% (24/25), ptfA was present in $92 \%$ $(23 / 25)$, and $p f h A$ was present in $60 \%(15 / 25)$. Gene toxA was not identified in any of the samples studied $(0 / 25)$. Five different genetic profiles were obtained, of which P1 (negative to toxA) was the most common. We concluded that the multiplex-PCR protocols could be useful tools for rapid and simultaneous detection of virulence genes. Despite the high frequency of the analyzed genes and the fact that all samples belonged to the same subspecies of $P$. multocida, five genetic profiles were observed, which should be confirmed in a study with a larger number of samples.
\end{abstract}

INDEX TERMS: Fowl cholera, avian pasteurellosis, virulence factors, multiplex-PCR, genetic profile.

RESUMO.- [Pesquisa de genes associados à virulência em cepas de Pasteurella multocida isoladas em casos de cólera aviária através da técnica de multiplex-PCR.] Os atuais sistemas de criação na avicultura, baseados na alta densidade populacional, aumentam os riscos de disseminação de patógenos, especialmente das doenças respiratórias e daquelas cujos agentes etiológicos possuam mais de um hospedeiro. A Cólera Aviária (CA) apresenta estas características e apesar de representar uma das patologias aviárias que deve ser considerada para o diagnóstico

\footnotetext{
${ }^{1}$ Received on October 19, 2012.

Accepted for publication on November 21, 2012.

${ }^{2}$ Centro de Diagnóstico e Pesquisa Aviária (CDPA), Faculdade de Veterinária, Universidade Federal do Rio Grande do Sul (UFRGS), Av. Bento Gonçalves 8824, Porto Alegre, RS 91540-000, Brazil. *Corresponding author: thales.furian@ufrgs.br
}

diferencial de enfermidades com notificação obrigatória que cursam com morte súbita, a patogenia e os fatores de virulência envolvidos na CA ainda estão pouco elucidados. 0 objetivo deste trabalho foi pesquisar doze genes associados à virulência em 25 amostras de Pasteurella multocida isoladas de casos de CA na região sul do Brasil através do desenvolvimento de protocolos de multiplex-PCR. Os protocolos de multiplex-PCR desenvolvidos foram capazes de detectar todos os genes propostos. Os genes ompH, oma87, sodC, $h g b A, h g b B$, exBD-tonB, nanB estiveram presentes em $100 \%$ das amostras $(25 / 25)$. Os genes sodA e nanH em $96 \%(24 / 25)$, o gene $p t f A$ em $92 \%(23 / 25)$ e o gene $p f h A$ em $60 \%(15 / 25)$. 0 gene toxA não foi identificado em nenhuma das amostras pesquisadas $(0 / 25)$. Foram obtidos cinco diferentes perfis genéticos, sendo P1 (negativo para o gene toxA) o mais comum. Com este trabalho, concluiu-se 
que os protocolos de multiplex-PCR desenvolvidos tornam-se uma ferramenta bastante útil e rápida para a detecção simultânea dos genes de virulência. Apesar da alta frequência dos genes estudados e de todas as amostras pertencerem à mesma subespécie de $P$. multocida, foram observados cinco perfis genéticos, os quais devem ser confirmados em um estudo com um maior número de amostras.

TERMOS DE INDEXAÇ̃̃O: Pasteurelose aviária, fatores de virulência, multiplex-PCR, perfil genético.

\section{INTRODUCTION}

The etiologic agent of Fowl Cholera (FC) is Pasteurella multocida, a gram-negative bacteria that also causes disease in other species of zootechnical interest, resulting in significant economic losses (Glisson 2008). FC is a septicemic disease usually characterized by high morbidity and mortality among poultry flocks (Nascimento et al. 2009). In the acute form of the disease, hyperemia, generalized congestion, petechiae or hemorrhages in different organs are observed. Sudden death without the presence of lesions can also occur. Chronic cases of the disease tend to be associated with an edematous site of infection (Charlton et al. 2006). Although it represents one of the oldest avian pathologies and is included in the differential diagnosis of notifiable diseases due to sudden death caused by avian influenza, the pathogenesis and virulence factors involved in FC are still poorly understood (Christensen \& Bisgaard 2006, Dziva et al. 2008).

The major virulence factors identified in P. multoci$d a$ are the capsule protein and lipopolysaccharide (LPS) (Harper et al. 2006). However, many other factors may be related, including genes encoding structures such as fimbriae and bacterial adhesins or outer membrane proteins (Corney et al. 2007, Hatfaludi et al. 2010). In addition, there are genes encoding enzymes involved in the uptake of iron, genes encoding enzymes involved in bacterial metabolism and genes that encode exotoxins (Harper et al. 2006).

Molecular strategies have been developed to identify genes related to virulence in $P$. multocida, but the frequency of these genes in different hosts is poorly defined (Mizan et al. 2000, Cox et al. 2003, Guenther et al., 2008, Bethe et al. 2009). Except for the studies that analyzed the molecular typing of capsules (Townsend et al. 2001, Leotta et al. 2006, Jabbari et al. 2006, Shivachandra et al. 2006, Bethe et al. 2009, Tang et al. 2009, Arumugam et al. 2011), a few experiments based on the detection of other virulence genes were developed using the multiplex-PCR technique, which consists of simultaneous amplification of multiple DNA regions (O.Henegariu et al. 1997). The aim of this study was to investigate twelve genes associated with virulence in samples of Pasteurella multocida isolated from cases of FC in southern Brazil through the development of three multiplex-PCR protocols.

\section{MATERIALS AND METHODS}

A total of 25 strains of Pasterella multocida were isolated from clinical cases of FC in the southern region of Brazil, and 6 strains were isolated from the lungs of swine at a slaughterhouse. Swine samples were selected to evaluate the compatibility of the multiplex-PCR protocols for detecting genes in strains from different animal species. All samples were stored in sheep blood at a temperature of $-80^{\circ} \mathrm{C}$. The isolates were reactivated in brain heart infusion broth (BHI-Oxoid®-Cambridge, UK) and incubated at $37^{\circ} \mathrm{C}$ for 24 hours. After this period, the isolates were plated on blood agar (Oxoid @-Cambridge, UK) supplemented with 5\% inactivated sheep serum and on MacConkey agar (Oxoid@-Cambridge, UK). The colonies from blood agar were evaluated according to their morphology. Catalase and oxidase tests were conducted in addition to the Giemsa stain for the purpose of observing the characteristics of the bacterial bipolar cells (Glisson et al. 2008).

An aliquot of $1 \mathrm{~mL}$ of a BHI overnight culture of each sample was separated for the extraction of DNA by heat treatment (Ewers

Table 1. The virulence genes selected, their enzymatic function or process, the primer sequences and the size of the amplicons

\begin{tabular}{|c|c|c|c|c|}
\hline Gene & Process or enzyme & Primer sequence $\left(5^{\prime}-3^{\prime}\right)$ & Amplicon (bp) & Reference \\
\hline ompH & porin & $\begin{array}{l}\text { CGCGTATGAAGGTTTAGGT } \\
\text { TTTAGATTGTGCGTAGTCAAC }\end{array}$ & 438 & Ewers et al. (2006) \\
\hline oma87 & porin & $\begin{array}{l}\text { ATGAAAAAACTTTTAATTGCGAGC } \\
\text { TGACTTGCGCAGTTGCATAAC }\end{array}$ & 948 & Ewers et al. (2006) \\
\hline $\operatorname{sod} A$ & superoxide dismutase & $\begin{array}{l}\text { TACCAGAATTAGGCTACGC } \\
\text { GAAACGGGTTGCTGCCGCT }\end{array}$ & 361 & Ewers et al. (2006) \\
\hline $\operatorname{sod} C$ & superoxide dismutase & $\begin{array}{l}\text { AGTTAGTAGCGGGGTTGGCA } \\
\text { TGGTGCTGGGTGATCATCATG }\end{array}$ & 235 & Lainson et al. (1996) \\
\hline$h g b A$ & iron uptake & $\begin{array}{l}\text { TGGCGGATAGTCATCAAG } \\
\text { CCAAAGAACCACTACCCA }\end{array}$ & 419 & Ewers et al. (2006) \\
\hline$h g b B$ & iron uptake & $\begin{array}{l}\text { ACCGCGTTGGAATTATGATTG } \\
\text { CATTGAGTACGGCTTGACAT }\end{array}$ & 788 & Ewers et al. (2006) \\
\hline $\operatorname{ex} B D$-ton $B$ & iron metabolism & $\begin{array}{l}\text { GGTGGTGATATTGATGCGGC } \\
\text { GCATCATGCGTGCACGGTT }\end{array}$ & 1144 & Ewers et al. (2006) \\
\hline $\operatorname{nan} B$ & sialidase & $\begin{array}{l}\text { GTCCTATAAAGTGACGCCGA } \\
\text { ACAGCAAAGGAAGACTGTCC }\end{array}$ & 554 & Ewers et al. (2006) \\
\hline nanH & sialidase & $\begin{array}{l}\text { GAATATTTGGGCGGCAACA } \\
\text { TTCTCGCCCTGTCATCACT }\end{array}$ & 360 & Ewers et al. (2006) \\
\hline$p t f A$ & type IV fimbriae & $\begin{array}{c}\text { TGTGGAATTCAGCATTTTAGTGTGTC } \\
\text { TCATGAATTCTTATGCGCAAAATCCTGCTGG }\end{array}$ & 488 & Doughty et al. (2000) \\
\hline pfhA & hemagglutinin & $\begin{array}{l}\text { AGCTGATCAAGTGGTGAAC } \\
\text { TGGTACATTGGTGAATGCTG }\end{array}$ & 275 & Ewers et al. (2006) \\
\hline tox $A$ & dermonecrotic toxin & CTTAGATGAGCGACAAGGTT GGAATGCCACACCTCTATA & 865 & Ewers et al. (2006) \\
\hline
\end{tabular}


Table 2. Multiplex-PCR protocols: virulence associated genes and PCR conditions

\begin{tabular}{|c|c|c|c|c|c|}
\hline \multirow[t]{2}{*}{ Multiplex } & \multirow{2}{*}{$\begin{array}{l}\text { Virulence-associated } \\
\text { genes }\end{array}$} & \multicolumn{4}{|c|}{ PCR conditions } \\
\hline & & Denaturation & Annealing & Elongation & $\begin{array}{l}\text { Numb } \\
\text { of cycl }\end{array}$ \\
\hline & & 9 & 55 & & 25 \\
\hline Multi & exBD-ton $B$, nanH, tox $A$ & $94^{\circ} \mathrm{C}-30$ seg & $55^{\circ} \mathrm{C}-30$ seg & $72^{\circ} \mathrm{C}$ - 90seg & 25 \\
\hline Multiplex 3 & oma87, sodC, $h g b B$, nanB & $94^{\circ} \mathrm{C}-30 \mathrm{seg}$ & $55^{\circ} \mathrm{C}-30 \mathrm{seg}$ & $72^{\circ} \mathrm{C}-60$ seg & 25 \\
\hline
\end{tabular}

Table 3. Multiplex-PCR: composition and concentration of the reaction mixture

\begin{tabular}{|c|c|}
\hline Multiplex-PCR & Reaction mixture \\
\hline Multiplex-PCR 1 & $\begin{array}{l}\text { 2. } \mu \mathrm{L} \text { of } 10 \mathrm{x} \text { PCR buffer, } 0.4 \mu \mathrm{L} \text { of } 10 \mathrm{mM} \text { deoxynucleo si- } \\
\text { de triphosphates, } 0.5 \mu \mathrm{L} \text { of } 10 \text { pmol primer pair (Invitro- } \\
\text { gen®-Carlsbad, USA), } 2 \mathrm{U} \text { of TaqPolimerase (Cenbiot-Porto } \\
\text { Alegre, Brazil), } 1.25 \mu \mathrm{L} \text { of } 2.5 \mathrm{mM} \mathrm{MgCl}, 5 \mu \mathrm{L} \text { of DNA }\end{array}$ \\
\hline Multiplex-PCR 2 & $\begin{array}{l}2.5 \mu \mathrm{L} \text { of } 10 \mathrm{x} \text { PCR buffer, } 0.4 \mu \mathrm{L} \text { of } 10 \mathrm{mM} \text { deoxynucleo- } \\
\text { side triphosphates, } 0.5 \mu \mathrm{L} \text { of } 10 \text { pmol primer pair (Invitro- } \\
\text { gen } 囚 \text {-Carlsbad, USA), } 2 \mathrm{U} \text { of TaqPolimerase (Cenbiot- Por- } \\
\text { to Alegre, Brazil), } 1.25 \mu \mathrm{L} \text { of } 2.5 \mathrm{mM} \mathrm{MgCl}_{2}, 5 \mu \mathrm{L} \text { of DNA }\end{array}$ \\
\hline Multiplex-PCR 3 & $\begin{array}{l}2.5 \mu \mathrm{L} \text { of } 10 \mathrm{x} \text { PCR buffer, } 0.4 \mu \mathrm{L} \text { of } 10 \mathrm{mM} \text { deoxynucleosi- } \\
\text { de triphosphates, } 0.5 \mu \mathrm{L} \text { of } 10 \mathrm{pmol} \text { primer pair (Invitro- } \\
\text { gen }(\text {-Carlsbad, USA), } 2 \mathrm{U} \text { of TaqPolimerase (Cenbiot-Por- } \\
\text { to Alegre, Brazil), } 1.25 \mu \mathrm{L} \text { of } 2.5 \mathrm{mM} \mathrm{MgCl}, 5 \mu \mathrm{L} \text { of DNA }\end{array}$ \\
\hline
\end{tabular}

et al. 2006). Prior to the study of virulence-associated genes, we performed a PCR protocol for species-specific amplification of the kmt gene, as described by Townsend et al. (1998). In this study, twelve virulence-associated genes $(\mathrm{ompH}$, oma87, $\operatorname{sod} A$, $\operatorname{sod} C$, $h g b A, h g b B$, exBD-ton $B, \operatorname{nan} B, \operatorname{nanH}, p t f A, p f h A$, toxA) were surveyed. The function of each one of the twelve genes studied, the sequence of each primer pair and the expected size of each amplicon are described in Table 1. The negative controls for PCR were selected among different members of the Pasteurellacea family (Reimerella anatipestier ATCC 11845, Mannheimia haemolytica ATCC 29694, Bordetella avium ATCC 35086, Pasteurella gallinarum ATCC 13360). The strains used as positive controls were Pasteurella multocida ATCC 15742, Pasteurella multocida ATCC 12945 and Pasteurella multocida ATCC 12946. Finally, a mix of all of the constituents of the PCR reaction mix without the addition of extracted DNA was used as a negative control.

Initially, individual PCR protocols were performed for each gene. The protocols followed the conditions described by Ewers et al. (2006). Subsequently, three multiplex-PCR protocols were

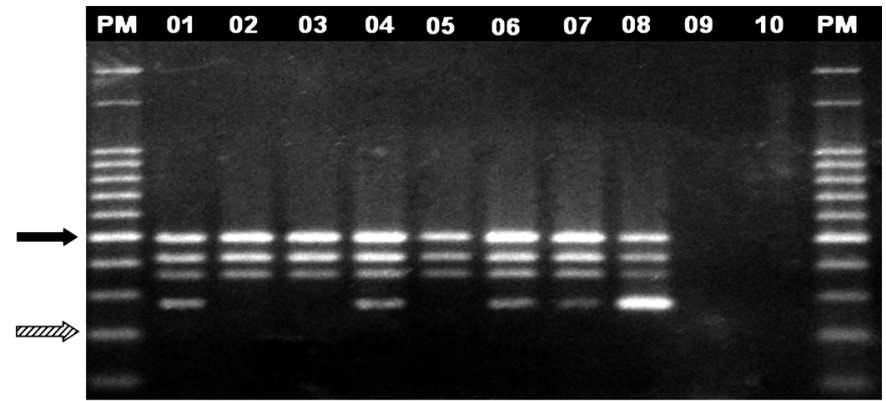

Fig.1. Electrophoresis on 1.5\% agarose gels stained with ethidium bromide and the amplification products associated with the genes studied (multiplex-PCR 1): ptfA (488bp); hgbA (419bp); $\operatorname{sod} A$ (361bp); $p f h A(275 b p)$. Legend: MW = molecular weight marker $(100 \mathrm{bp})=01-07$ samples; $08=$ Pasteurella multocida ATCC 12945; 09 = Mannheimia haemolytica ATCC 29694, 10 = control reaction. The dashed arrow indicates a fragment of $200 \mathrm{bp}$; the filled arrow indicates a fragment of 500bp.
Table 4. Frequency of virulence-associated genes in 25 samples of Pasteurella multocida of avian origin

\begin{tabular}{lccccc}
\hline \multirow{2}{*}{ Gene } & \multicolumn{2}{c}{ Positive strains } & & \multicolumn{2}{c}{ Negative strains } \\
\cline { 2 - 3 } \cline { 5 - 6 } ompH & Total $(\mathrm{n}=25)$ & Total $(\%)$ & & Total $(\mathrm{n}=25)$ & Total (\%) \\
\hline oma87 & 25 & 100 & & 0 & 0 \\
sodA & 25 & 100 & & 0 & 0 \\
sodC & 24 & 96 & & 1 & 4 \\
hgbA & 25 & 100 & & 0 & 0 \\
hgbB & 25 & 100 & & 0 & 0 \\
exBD-tonB & 25 & 100 & & 0 & 0 \\
nanB $B$ & 25 & 100 & & 0 & 0 \\
nanH & 25 & 100 & & 0 & 0 \\
ptfA & 24 & 96 & & 1 & 4 \\
pfhA & 23 & 92 & & 2 & 8 \\
toxA & 15 & 60 & & 10 & 40 \\
& 0 & 0 & & 25 & 100
\end{tabular}

established (Table 2) to allow the simultaneous detection of the virulence genes. For each amplification reaction, a mixture of reagents $(25 \mu \mathrm{l})$ was prepared whose composition and concentration are described in Table 3. The amplification reactions were performed in a thermocycler (Swift MaxPro Thermal Cycler-ESCO Technologies ${ }^{\circledR}$ ) according to the reaction conditions described in Table 2. Electrophoresis of the amplified products was carried out in $1 \%$ and $1.5 \%$ agarose gels (Invitrogen UltrapureTM Agarose $囚-$ Carlsbad, USA) stained with ethidium bromide, and the amplified products were visualized in an ultraviolet light transluminator (Pharmacia LKB MacroVue ${ }^{\circledR}$ ). The ompH gene was not selected for the multiplex-PCR protocols because its primers had a ratio of purine to pyrimidine bases (guanine/cytosine) lower than $40 \%$.

\section{RESULTS}

The multiplex-PCR protocols developed were able to detect all of the target genes in samples of avian and porcine origin, and the results obtained for all strains in the individual PCRs were similar to those obtained by simultaneous amplification of the genes. Likewise, both protocols were specific to the genes selected, and amplification did not occur in extracts of strains selected as negative controls (Fig.1). The frequency of virulence-associated genes is displayed in Tables 4 and 5. Five different genetic profiles (P1 - P5) were obtained among the 25 strains of avian origin, and profile $\mathrm{P} 1$, expressing all genes except tox $A$, was the most common (Table 6).

\section{DISCUSSION}

Despite the economic importance of infections caused by Pasteurella multocida, the mechanisms by which this agent causes different diseases are still poorly understood (Harper et al. 2006). The high antigenic variability and the different hosts and courses of infection complicate the establishment of an efficient vaccine (Davies et al. 2003). There 
Table 5. Frequency of virulence-associated genes in 6 samples of Pasteurella multocida of porcine origin

\begin{tabular}{lccccc}
\hline \multirow{2}{*}{ Gene } & \multicolumn{2}{c}{ Positive strains } & & \multicolumn{2}{c}{ Negative strains } \\
\cline { 2 - 3 } \cline { 5 - 6 } & Total $(\mathrm{n}=6)$ & Total $(\%)$ & & Total $(\mathrm{n}=6)$ & Total $(\%)$ \\
\hline ompH & 6 & 100 & & 0 & 0 \\
oma87 & 6 & 100 & & 0 \\
sodA & 6 & 100 & & 0 \\
sodC & 6 & 100 & & 0 & 0 \\
hgbA & 6 & 100 & & 0 & 0 \\
hgbB & 2 & 33 & & 4 & 67 \\
exBD-tonB & 6 & 100 & & 0 & 0 \\
nanB & 6 & 100 & & 0 \\
nanH & 6 & 100 & & 0 & 0 \\
ptfA & 6 & 100 & & 0 & 0 \\
pfhA & 4 & 67 & & 2 & 33 \\
toxA & 0 & 0 & & 6 & 100
\end{tabular}

Table 6. Distribution of genetic profiles in 25 samples of Pasteurella multocida of avian origin

\begin{tabular}{ccc}
\hline Genetic profile & Number of strains & Absent genes \\
\hline P1 & 12 & tox $A ; d c b F ; b c b D$ \\
P2 & 9 & toxA; $p$ fhA, $d c b F ; b c b D$ \\
P3 & 2 & tox $; p f t A$ \\
P4 & 1 & tox $A$, nanH \\
P5 & 1 & toxA; $p$ fhA; $\operatorname{sod} A$
\end{tabular}

are only a few studies that aim to detect or to determine the frequency of virulence gene patterns (Ewers et al. 2006, Atashpaz et al. 2009, Bethe et al. 2009, Shayegh et al. 2009, Tang et al. 2009). There are even fewer data available examining strains of avian origin.

The multiplex-PCR protocols gave the same results as individual protocols. Multiplex PCR represents an important tool for the diagnosis and study of a large number of samples because it allows the simultaneous detection of multiple genes, reducing the amount of reagents used and time required to obtain the results (Markoulatos et al. 2002, Perry et al. 2007). The individual PCR protocols and multiplex-PCR also performed well in the detection of virulence genes in samples of porcine origin.

The oma87 and ompH genes, which encode porins of P. multocida, were detected in $100 \%$ of the analyzed samples, which is consistent with other studies (Davies et al. 2004, Ewers et al. 2006, Bethe et al. 2009). The porins are candidates for heterologous vaccine development because they are generally conserved among species and highly immunogenic. The immunogenicity is related to hydrophilic portions of $\mathrm{OmpH}$, which are predicted to be extracellular domains, exposing epitopes on the bacterial surface (Lee et al. 2007). Purified proteins or amplicons of $o m p H$ and oma87 genes can also be used to assess intra-species differences and determine epidemiological relationships (Davies et al. 2003). All avian samples showed $\operatorname{sod} C$, and only one was negative for sodA. The enzymes encoded by these genes have antioxidant functions, and they were only described after genome sequencing of the strain Pm70 in 2001 (May et al. 2001). Our results are similar to those found in Germany by Ewers et al. (2006), who detected the presence of these two genes in $100 \%$ of 289 strains of $P$. multocida isolated from different species, including 20 samples from chickens.
Among the three genes involved in iron metabolism selected for the study, all were present in the 25 samples of avian origin. The results for exBD-tonB and $h g b A$ are consistent with the findings of previous works (Ewers et al. 2006, Bethe et al. 2009). The TonB complex, composed of three proteins, is responsible for the proton motive force required to internalize iron into the periplasmic space (Krewulak \& Vogel 2008). As the energy generated by the complex is required for different mechanisms of iron uptake (Hatfaludi et al. 2010), the frequency normally expected for the genes encoding the proteins of this complex is $100 \%$ (Bethe et al. 2009). hgbA is an example of a protein present in the outer bacterial membrane that binds to host glycoproteins that contain iron, in this case hemoglobin (Boyce et al. 2010). The high prevalence of iron uptake genes in $P$. multocida, as well as their crucial role in the pathogenesis of $\mathrm{FC}$, makes their products attractive vaccine candidates (Ewers et al. 2006), as was observed in other members of the Pasteurellaceae family (Potter et al. 1999). In the only other work that investigated the presence of the $h g b B$ gene in chickens, Ewers et al. (2006) reported a frequency of greater than $85 \%$. Furthermore, we only detected this gene in 2 of 6 samples from swine (33\%). Bethe et al. (2009) obtained similar results, detecting $h g b B$ less frequently in diseased pigs than in healthy animals. Shayegh et al. (2008) reported similar results analyzing samples from clinically healthy sheep and animals with respiratory signs. In both cases, no correlation between the presence of $h g b B$ and the diseases caused by P. multocida was reported. A greater number of samples, including isolates from healthy animals, is necessary to further evaluate this hypothesis.

Two genes that encode sialidases, $n a n B$ and $n a n H$, were identified in 25/25 (100\%) and 24/25 (96\%) avian samples, respectively. The nanB gene was also detected in all samples in other studies (Mizan et al. 2000, Ewers et al. 2006, Bethe et al. 2009). The frequency of nanH was similar to that cited by Bethe et al. (2009), but it differs from Ewers et al. (2006) who detected this gene in $65 \%$ of samples. The sialidases are enzymes that remove sialic acid conjugated to glycoproteins and glycolipids of eukaryotic cells (Hatfaludi et al. 2010). Sialic acid is then used as carbon source by the bacteria, or it is incorporated into the outer membrane, aiding in the infectious process and in the inhibition of the host immune system (Vimr \& Litchtensteiger 2002).

Bacterial adhesion to host cells is a basic prerequisite for initial infection; therefore the genes involved in this step are constant targets for the analysis of virulence genotypes in P. multocida (Hatfaludi et al. 2010). It is believed that among the adhesins identified in samples of $P$. multocida, including $p f h A, t a d, p t f A$, fimA, and $h s f-1,2$, only the latter three are present in all pathogenic strains (Sellyei et al. 2010). The ptfA gene, which encodes a subunit of type IV fimbriae, was found in 23/25 samples (92\%), a result similar to that observed in other studies (Ewers et al. 2006, Bethe et al. 2009, Tang et al. 2009). The Type IV fimbriae are formed by repeated subunits and present a highly conserved $\mathrm{N}$-terminal nucleotide sequence (Hatfaludi et al. 2010). In a recent study, Sellyei et al. (2010) identified only two major alleles of $p t f A$ among 31 strains of different sero- 
types and serogroups isolated from poultry. The presence of the alleles is correlated with the clinical severity of FC. For these reasons, despite the variations in immunogenicity among strains of $P$. multocida observed by Doughty et al. (2000), this gene is a candidate for heterologous vaccine development (Ewers et al. 2006).

The hemagglutinin PfhA was identified in 15/25 strains $(60 \%)$. This lower frequency was also found in other studies. Ewers et al. (2006) detected pfhA in $45 \%$ of 20 avian samples analyzed. The same authors observed a variation in frequency between 7 and $100 \%$ according to the species studied and correlated the presence of the gene to the occurrence of pasteurellosis in cattle. Bethe et al. (2009) found a correlation between the presence of $p f h A$ and the occurrence of respiratory disease in swine. However, Shayegh et al. (2008) reported a low percentage of $p f h A$ in sheep and observed a correlation between the presence of the gene and disease in this species. Different authors have all reported that strains of capsular type A have a high frequency of $p f h A$. In a study of 233 samples of $P$. multocida isolated from respiratory tracts of swine in China, Tang et al. (2009) detected the presence of $p f h A$ in $25 \%$ of strains of serogroup A and in only $3.1 \%$ of samples of type D. The association between $p f h A$ and the capsule type A gene is not physical because they are separated by a region of 839 $\mathrm{kb}$ in the genome of strain Pm70 (May et al. 2001). It is believed that some clones have acquired $p f h A$ by horizontal gene transfer, thus obtaining a survival advantage in the host. However, the reason that this acquisition occurs more frequently in type A strains is unclear (Bethe et al. 2009).

None of the 25 strains of avian origin analyzed in this study contained the tox $A$ gene, the only exotoxin described in the species. Ewers et al. (2006) also found a low frequency of this gene, which was detected in only $5 \%$ of the strains isolated from poultry. While Dziva et al. (2004) only found tox $A$ in samples of serogroup $D$ isolated from cases of progressive atrophic rhinitis in pigs, other studies detected it in strains of serogroup A and in different hosts (Zaglic et al. 2005), including humans (Donnio et al. 1999). Shayegh et al. (2008) detected the gene in $70 \%$ of strains isolated from diseased sheep. In 2009, the same authors identified toxigenic strains of $P$. multocida in goats with respiratory symptoms. The presence of toxA could be associated with cases of pneumonia in these species, as occurs in atrophic rhinitis in pigs (Shayegh et al. 2009). This relationship is not established in poultry.

Five different genetic profiles were obtained from the 25 avian samples in the experiment. We expected that most samples would present a high frequency of all the genes studied because all the strains were isolated from clinical cases of FC. We performed a qualitative analysis of the distribution of the genetic profiles in our samples, evaluating only the presence or absence of the genes and establishing a linear relationship among the samples, without considering gene expression. Obtaining strains from different sources and studying groups of samples isolated from healthy and diseased animals may reveal a possible epidemiological link between a specific group of genes and the development of FC in acute or chronic cases.

\section{CONCLUSIONS}

The multiplex-PCR protocols that we developed showed the same results as those obtained using individual protocols, making them a useful tool for the simultaneous detection of virulence genes in future studies with larger numbers of samples.

The high frequency of virulence-associated genes detected in the analyzed samples suggests its importance in the manifestation of FC.

On the other hand, differences in the frequency of these genes may indicate variations in the pathogenicity of Pasteurella multocida.

Acknowledgments.- To The National Council for Scientific and Technological Development (CNPq) and to the Ministry of Agriculture, Livestock and Food Supply (MAPA) for funding this project.

\section{REFERENCES}

Arumugam N.D., Ajam N., Blackall P.J., Asiah N.M., Ramlan M., Maria J., Yuslan S. \& Thong K.L. 2011. Capsular serotyping of Pasteurella multocida from various animal hosts - a comparison of phenotypic and genotypic methods. Trop. Biomed. 28:55-63.

Atashpaz S., Shayegh J. \& Hejazi M.S. 2009. Rapid virulence typing of Pasteurella multocida by multiplex PCR. Res. Vet. Sci. 87:355-357.

Bethe A., Wieler L.H., Selbitz H.J. \& Ewers C. 2009. Genetic diversity of porcine Pasteurella multocida strains from the respiratory tract of healthy and diseased swine. Vet. Microbiol. 139:97-105.

Boyce J.D., Harper M., Wilkie I.W. \& Adler B. 2010. Pasteurella, p.325-346. In: Gyles C.L., Prescott J.F., Songer G. \& Thoen C.O. (Eds), Pathogenesis of Bacterial Infections in Animals. $4^{\text {th }}$ ed. Blackwell Publishing, Ames.

Charlton B.R., Bermudez A.J., Boulianne M., Halvorson D.A., Schrader J.S., Newman L.J., Sander J.E. \& Wakenell P.S. 2006. Fowl cholera, p.84-87. In: Charlton B.R. (Ed.), Avian Disease Manual. $6^{\text {th }}$ ed. American Association of Avian Pathologists, Athens.

Christensen H. \& Bisgaard M. 2006. The genus Pasteurella, p.1062-1090. In: Dworkin M. (Ed.), The Prokaryotes. $3^{\text {rd }}$ ed. Springer, New York.

Corney B.G., Diallo I.S., Wright L.L., Hewitson G.R., De Jong A.J., Burrell P.C., Duffy P.F., Stephens C.P., Boyle D.B. \& Blackall P.J. 2007. Pasteurella multocida detection by $5^{\prime}$ Taq nuclease assay: a new tool for use in diagnosing fowl cholera. J. Microbiol. Methods 69:376-380.

Cox J., Hunt M.L., Boyce J.D. \& Adler B. 2003. Functional characterization of $\mathrm{HgbB}$, a new hemoglobin binding protein of Pasteurella multocida. Microb. Pathog. 34:287-296.

Davies R.L., MacCorquodale R. \& Caffrey B. 2003. Diversity of avian Pasteurella multocida strains based on capsular PCR typing and variation of the $\mathrm{OmpA}$ and $\mathrm{OmpH}$ outer membrane proteins. Vet. Microbiol. 91:169182.

Davies R.L., MacCorquodale R. \& Reilly S. 2004. Characterization of bovine strains of Pasteurella multocida and comparison with isolates of avian, ovine and porcine origin. Vet. Microbiol. 99:145-158.

Donnio P.Y., Allardet-Servent A., Perrin M., Escande F. \& Avril J.L. 1999. Characterisation of dermonecrotic toxin-producing strains of Pasteurella multocida subsp. multocida isolated from man and swine. J. Med. Microbiol. 48:125-131.

Doughty S.W., Ruffolo C.G. \& Adler B. 2000. The type 4 fimbrial subunit gene of Pasteurella multocida. Vet. Microbiol. 72:79-90.

Dziva F., Christensen H., Van Leengoed L.A.M.G., Mohan K. \& Olsen J.E. 2004. Differentiation of Pasteurella multocida isolates from cases of atrophic rhinitis in pigs from Zimbabwe by RAPD and ribotyping. Vet. Microbiol. 102:117-122.

Dziva F., Muhairwa A.P., Bisgaard M. \& Christensen H. 2008. Diagnostic and typing options for investigating disease associated with Pasteurella multocida. Vet. Microbiol. 128:1-22. 
Ewers C., Lübke-Becker A., Bethe A., Kiebling S., Filter M. \& Wieler L.H. 2006. Virulence genotype of Pasteurella multocida strains isolated from different hosts with various disease status. Vet. Microbiol. 114:304-317.

Glisson J.R. 2008. Pasteurellosis and others respiratory bacterial infection, p.739-758. In: Saif Y.M. (Ed.), Diseases of Poultry. $12^{\text {th }}$ ed. Blackwell Publishing, Iowa.

Glisson J.R., Sandhu T.S. \& Hofacre C.L. 2008. Pasteurellosis, avibacteriosis, gallibacteriosis, riemerellosis and pseudotuberculosis, p.12-18. In: Dufour-Zavala L. (Ed.), A Laboratory Manual for the Isolation, Identification and Characterization of Avian Pathogens. $5^{\text {th }}$ ed. American Association of Avian Pathologists, Georgia.

Guenther S., Schierack P., Grobbel M., Becker A.L., Wieler L.H. \& Ewers C. 2008. Real-time PCR assay for the detection of species of the genus Mannheimia. J. Med. Microbiol. 75:75-80.

Harper M., Boyce J.D. \& Adler B. 2006. Pasteurella multocida pathogenesis: 125 years after Pasteur. FEMS Microbiol. Lett. 265:1-10.

Hatfaludi T., Al-Hasani K., Boyce J.D. \& Adler B. 2010. Outer membrane proteins of Pasteurella multocida. Vet. Microbiol. 144:1-17.

Henegariu O., Heerema N.A., Dlouhy S.R., Vance G.H. \& Vogt P.H. 1997. Multiplex PCR: critical parameters and step-by-step protocol. Biotechniques 23:504-511.

Jabbari A.R., Esmaelzadeh M. \& Moazeni Jula Gh.R. 2006. Polymerase chain reaction of Pasteurella multocida capsules isolated in Iran. Iran J. Vet. Res. 7:50-55.

Jaglic Z., Kucerova Z., Nedbalcova K., Pavlik I., Alexa P. \& Bartos M. 2005. Characterisation and comparison of Pasteurella multocida isolated from different species in the Czech Republic: capsular PCR typing, ribotyping and dermonecrotoxin production. Vet. Med. Czech. 50(8):345-354.

Krewulak K.D. \& Vogel H.J. 2008. Structural biology of bacterial iron uptake. Biochim. Biophys. Acta 1778:1781-1804.

Lee J., Kim Y.B. \& Kwon M. 2007. Outer membrane protein $\mathrm{H}$ for protective immunity against Pasteurella multocida. J. Microbiol. 45:179-184.

Leotta G.A., Vigo G.B., Chinen I., Prieto M., Callejo R. \& Rivas M. 2006. Identificación, biotipificación y caracterización de cepas de Pasteurella multocida aisladas en la Argentina. Revta Argent. Microbiol. 38:125-129.

Markoulatos P., Siafakas N. \& Moncany M. 2002. Multiplex polymerase chain reaction: a pratical approach. J. Clin. Lab. Anal. 16:47-51.

May B.J., Zhang Q., Li L.L., Paustian M.L., Whittam T.S. \& Kapur V. 2001.
Complete genomic sequence of Pasteurella multocida, Pm70. Proc. Natl Acad. Sci. USA 98:3460-3465.

Mizan S., Henk A., Stallings A., Maier M. \& Lee M.D. 2000. Cloning and characterization of sialidases with 2-6' and 2-3' sialyc lactose specifity from Pasteurella multocida. J. Bacteriol. 182:6874-6883.

Nascimento V.P., Gama N.M.S.Q. \& Canal C.W. 2009. Coriza infecciosa das galinhas, pasteureloses e outras infecções bacterianas relacionadas, p.503-530. In: Berchieri Júnior A., Silva E.N., Di Fábio J., Sesti L. \& Zuanaze M.A.F. (Eds), Doenças das Aves. $2^{\underline{a}}$ ed. FACTA, Campinas.

Perry L., Heard P., Kane M., Kim H., Savikhin S., Dominguez W. \& Applegate B. 2007. Application of multiplex polymerase chain reaction to the detection of pathogens in food. J. Rapid Autom. Microbiol. 15:176-198.

Potter A.A., Schryvers A.B., Ogunnariwo J.A., Hutchins W.A., Lo R. \& Watts T. 1999. Protective capacity of the Pasteurella haemolytica transferrin-binding proteins TbpA and TbpB in cattle. Microb. Pathog. 27:197-206.

Sellyei B., Bányai K. \& Magyar T. 2010. Characterization of the ptfA gene of avian Pasteurella multocida strains by allele-specific polymerase chain reaction. J. Vet. Diagn. Invest. 22:607-610.

Shayegh J., Atashpaz S. \& Hejazi M.S. 2008. Virulence genes profile and typing of ovine Pasteurella multocida. Asian J. Anim. Vet. Adv. 3:206-213.

Shayegh J., Sharaf J.D., Mikaili P. \& Namvar H. 2009. Pheno-and genotyping of Pasteurella multocida isolated from goat in Iran. Afr. J. Biotechnol. 8:3707-3710.

Shivachandra S.B., Kumar A.A., Gautam R., Singh V.P., Saxena M.K. \& Srivastava S.K. 2006. Identification of avian strains of Pasteurella multocida in India by conventional and PCR assays. Vet. J. 172:561-564.

Tang X., Zhao Z., Hu J., Wu B., Cai X., He Q. \& Chen H. 2009. Isolation, Antimicrobial Resistance, and Virulence Genes of Pasteurella multocida strains from swine in China. J. Clin. Microbiol. 47:951-958.

Townsend K.M., Frost A.J., Lee C.W., Papadimitriou J.M. \& Dawkins H.J.S. 1998. Development of PCR assays for species- and type-specific identification of Pasteurella multocida isolates. J. Clin. Microbiol. 16:10961100.

Townsend K.M., Boyce J.D., Chung J.Y., Frost A.J. \& Adler B. 2001. Genetic organization of Pasteurella multocida cap loci and development of a multiplex capsular PCR typing system. J. Clin. Microbiol. 39:924-929.

Vimr E. \& Licjtensteiger C. 2002. To sialylate, or not to sialylate: that is the question. Trends Microbiol. 10:254-257. 